\title{
THE ROLE OF MICROFINANCE FOR HOUSING OF LOW-INCOMES: THE CASE OF BALTIMORE
}

\author{
ANTHONY SCOTT \\ Mayor's Office, Baltimore, Maryland, United States.
}

\section{LAURO GONZALEZ}

Escola de Administração de Empresas de São Paulo, São Paulo, São Paulo, Brazil.

\section{TANIA PEREIRA CHRISTOPOULOS}

Universidade de São Paulo, São Paulo, São Paulo, Brazil.

To cite this paper: Scott, A., Gonzalez, L., \& Christopoulos, T. P. (2018). The role of microfinance for housing of low-incomes: The case of Baltimore. Revista de Administração Mackenzie, 19(1). doi 10.1590/1678-6971/eRAMG180089

Submission: Aug. 11, 2017. Acceptance: Nov. 28, 2017.

\section{(cc) BY} This is an open-access article distributed under the terms of the Creative Commons Attribution License.

\footnotetext{
This paper may be copied, distributed, displayed, transmitted or adapted if provided, in a clear and explicit way, the name of the journal, the edition, the year and the pages on which the paper was originally published, but not suggesting that RAM endorses paper reuse. This licensing term should be made explicit in cases of reuse or distribution to third parties. It is not allowed the use for commercial purposes.

Este artigo pode ser copiado, distribuído, exibido, transmitido ou adaptado desde que citados, de forma clara e explícita, o nome da revista, a edição, o ano e as páginas nas quais o artigo foi publicado originalmente, mas sem sugerir que a RAM endosse a reutilização do artigo. Esse termo de licenciamento deve ser explicitado para os casos de reutilização ou distribuição para terceiros. Não é permitido o uso para fins comerciais.
} 


\section{ABSTRACT}

Purpose: This study proposes to map the barriers to scaling the microfinance industry in the U.S., as it pertains to home maintenance and improvement for low-income households. The selected context of analysis is the American city of Baltimore, due to the city's high need for housing repair and large percentage of residents with limited access to finance.

Originality/Value: Most research has discarded microfinance as a viable option for a housing market solution in the U.S. This paper discusses how the market of microfinance for housing repair could improve its financial sustainability seizing the smaller dollar value of repair loans, relative to housing purchase, and the high and recurring need for repair. Design/methodology/approach: Qualitative research was conducted on how microfinance for housing repair works in Baltimore City, leveraging secondary government and private research, along with interviews with lenders and borrowers. Data were analyzed through PESTEL framework, describing the macro-environmental context.

Findings: The market for Housing Microfinance (HM) loan products in Baltimore matches the academic literature. Similar market demands exist as they relate to an increasingly aging housing stock. Lender supply of financing seems "healthy", but it is mostly from philanthropic or government sources favoring "affordability" over financial sustainability.

\section{KEYWORDS}

Microfinance. Housing. Baltimore. Financially self-supporting microcredit. Subsidized housing. 


\section{INTRODUCTION}

In 2003, the U.S. Department of Housing and Urban Development (HUD, 2016) estimated that the United States needed \$1.3 trillion in rehabilitation of aging housing stock, but that $40 \%$ of that funding was unaffordable without some measure of government subsidy or other means of support (e.g., "Sweat equity" or staggering improvements over time) (Listokin \& Crossney, 2006). Thereafter, the U.S. government has been searching for ways to close this gap. This mismatch between the costs of rehabilitation and the financial resources and instruments available is worse for minorities and the poor in the U.S., who often find themselves in older housing stock and without the means to make the needed repairs.

Ever since microfinance gained force in the United States in the early 1990s, American microfinance institutions (MFI) have been trying to figure out what role microfinance plays in the American financial system. Initially, the U.S. bought into the microcredit's theory of change as a vehicle to help the poor set up new microenterprises and startups, with the hopes of creating economic growth and an exit out of poverty. Unlike developing countries, however, microfinance never developed a strong role in the U.S. financial market. In 2012, the U.S. microfinance industry served about 361,460 people with a total loan volume of $\$ 366$ million, while the Brazilian industry - a country of comparable population, for example - served over 3 million people with a volume of $\$ 2.5$ billion (FIELD, 2015; Microfinance Information Exchange, 2016). When it comes to microfinance specifically for housing in the U.S., the sector is virtually non-existent. This is largely due to housing being more expensive to build and maintain, as a result of the U.S. debt-heavy model requiring homeowners to buy their entire house upfront (i.e. not allowing incremental or "progressive" building). This fact alone makes microfinance services less economically feasible for the poor, who would have to take out larger loans, and for MFIs, who would have to provide larger loans to a riskier clientele. Consequently, most research has discarded microfinance as a viable option for a housing market solution, resulting in lack of analysis for its potential use in home improvements and repairs. The key assumption this paper makes is that the microfinance for housing repair market might be more financially sustainable in the U.S. due to the smaller dollar value of repair loans, relative to housing purchase, and the high and recurring need for repair that is unlike microloans to businesses.

This paper makes a first attempt at analyzing and mapping the barriers to scaling the microfinance industry in the U.S., as it pertains to home 
maintenance and improvement for low-income households. It will use the American city of Baltimore as the context for analysis, due to the city's high need for housing repair and large percentage of residents with limited access to finance. Analysis relies on U.S. Census data and private analysis university and non-profit - as well as qualitative interviewing of both lenders and borrowers to map out a nuanced market context. The goal of this paper's market diagnostic is to help MFIs, who want to expand into housing finance, to understand the main challenges to sustainable market entry in the U.S., as well as highlight areas for further research into sustainably financing housing repairs for the poor.

In order to gain an understanding of the unique challenges of microfinance generally within the U.S. context, the paper begins with the evolution of academic literature on microfinance in the U.S. along with its shortcomings. After the literature review, the paper will lie out the methodology used, the research design, and the plan, followed by a report of the results of that research. It will conclude with an analysis of the findings in order to address the research question: How can microfinance apply to housing repair in the U.S.?

\section{LITERATURE REVIEW}

\subsection{Microfinance in the United States}

Renewing faith in private markets to help eliminate poverty, MFIs grew rapidly during the emergence of neoliberalism in the 1980s, now serving over 200 million clients worldwide. In the 1990s, microfinance became a more widely discussed topic in the U.S. after then-President Bill Clinton spearheaded it during his presidency. In 1991, the Association for Enterprise Opportunity became the first member-based microfinance trade association in the U.S. Within a year, the association successfully advocated for the U.S. Small Business Administration [SBA] to implement the Microloan Demonstration Program (Carr \& Tong, 2002). Funding was initially awarded to 35 microfinance organizations in 1992, and by 1997 the pilot had become a permanent program. Today in the U.S., nearly 200 microfinance organizations receive funds from the federal government through the SBA, and several hundred others in the U.S. operate without SBA assistance (Carr \& Tong, 2002).

Initially, the U.S. saw microfinance as a way to help the poor set up new microenterprises and startups, with the hopes of creating economic growth (Schreiner \& Morduch, 2002). Nonetheless, studies from Bhatt (2002), 
Bates and Servon (2002), and Taub (2002) all found that scale and financial independence all proved unsustainable in the U.S. context. Out of the top 50 microfinance institutions in the world, none are in the U.S. (Swibel, 2007). Schreiner \& Morduch (2002) argue that there are six main reasons for the anemic performance of microfinance in the U.S.:

1. The size of the microenterprise sector is small. Compared to developing countries, microfinance in the U.S. serves a very small population. In 2012, the U.S. microfinance industry served about 361,460 people with a total loan volume of $\$ 366$ million, while the Brazilian industry - a country of comparable population, for example - served over 3 million people with a volume of $\$ 2.5$ billion (FIELD, 2015; Microfinance Information Exchange, 2016).

2. The government safety net is functional. Since 1996, with the welfare reform law, the U.S. has a public safety net that reduces the pressure for selfemployment, giving people time to look for new wage employment in the formal sector. This fact might even reduce entrepreneurialism as the expectation of a safety net teaches people not to look for self-employment in bad economic times (Novograt, 1992).

3. Competition from large firms limits true scale. Competition against large firms in the U.S. means that micro entrepreneurs are unlikely to be able to compete on price or quality against the imported goods made by lower-wage workers. This pushes micro entrepreneurs into niche, often service-oriented markets that do not pay well (Schreiner \& Morduch, 2002).

4. It is hard to compete with easy credit. Microfinance's largest competitor in the U.S. is credit cards, which are more accessible to the poor in the U.S. - especially if they have a good credit history (Schreiner \& Morduch, 2002). According to the National Small Business Association (2012), $37 \%$ of small businesses use credit cards to finance their business, second only to a "revolving line of credit from a [formal] bank [43\%]" (Access to Capital Survey, 4)

5. Microfinance for housing in the U.S. is more complex. Unlike developing countries, in the U.S. few poor people build their own homes. For legal reasons, larger home improvements are often left to professionals; for safety and to protect the value of neighboring houses, local governments make and enforce building codes and zoning laws. These factors constrain access to small, low-cost houses because they increase minimum cost of a house and limit progressive improvements once a home is built (Schreiner \& Morduch, 2002). 
6. Group lending does not work well in the US. While using neighbors and demographically similar lenders as collateral has worked in developing countries, the U.S. context, which is more culturally diverse, individualistic and physically mobile, has found leveraging social capital to be a less valued and effective tool (Schreiner \& Morduch, 2002).

Consequently, the growth of microfinance has been limited. To improve results, the sector in the U.S. has increasingly turned towards financial education, a preference for individual lending, and diversification to include better-off clients (Schreiner \& Morduch, 2002; Armendáriz \& Morduch, 2005). While these barriers persist, the recent U.S. recession might weaken some of them as credit has become less available. The fact that the number of individuals served by MFIs has more than doubled since 2008 (>130\% growth), along with a tripling of loan volume, is suggestive of the recession's impact on increasing demand for microloan services (Girardo \& Edgcomb, 2011). While concerns have surfaced over microloans creating a new "subprime" bubble, the fact that U.S. financial institutions largely rely on national credit rating scores, reduces the risk of loaning to someone whose debt-to-income ratio is unsustainable (Hahn, 2008).

\subsection{Housing Microfinance for house purchase/construction/ rehabilitation}

Much like microfinance, classical Housing Microfinance (HMF) is not a subsidy-driven model but a market-based, demand-driven solution that has made housing an affordable and economically viable option for low-income households, addressing a market failure to extend traditional means of housing finance to low and moderate-income households (Huh \& Kolluri, 2004). Over time, HMF came to encapsulate any financial institution, whether a credit union with flexible terms or a stand-alone MFI that loans to low-income people for renovation or expansion of an existing home, construction of a new home, land acquisition, or basic infrastructure. Conceptually, HMF developed out of a realization that microentrepreneurs often use their homes as productive assets in generating income. A report issued by the U.S. Agency for International Development (Housing Microfinance Initiatives, 2000) confirmed and aggregated its previous studies, along with those from the World Bank (1999), concluding that there was a growing field of home construction and improvement microloans in MFI's across various countries (Housing Microfinance Initiatives, 2000). 
Unlike in developing countries, however, microfinance in the U.S. never developed a strong role in the housing market. As previously mentioned, this is partly because housing in the U.S. is more expensive to build and maintain, due to stricter housing standards and regulation. Additionally, the U.S. housing finance model is "debt-heavy and does not account for drops in income, changes in family size, or increases in housing expenses over time" (Huh \& Kolluri, 2004). These structural factors make the HMF market for house purchase less economically viable for the poor (Louie, Belsky, \& McArdle, 2004) and less economically sustainable for microfinance institutions (Daphnis, 2004).

To understand HMF in the U.S. it is necessary to report the wider range of government programs and subsidies that service housing for the poor. Since the passage of the Housing and Community Development Act of 1974, a number of social programs became targeted at making housing purchase and maintenance more affordable for the poor. As a consequence, the Community Development Block Grant (CDBG) program came online, in part, helping existing homeowners repair and rehabilitate their homes. In 1977, the Community Reinvestment Act (CRA) required federally-regulated banks to extend credit to low-income communities, in which they were chartered, leading to a range of new lending products targeted to areas that counted toward CRA (Williams, 2004). This was followed by the 1978 Neighborhood Reinvestment Act, which chartered branches across the country with the mission to promote affordable housing and community development through grants and training to local institutions.

Maybe the most significant government intervention was the Federal Housing Enterprises Financial Safety and Soundness Act in 1992, which forced the largest government housing finance lenders, Fannie Mae and Freddie Mac, to serve lower-income families and lower-income and minority neighborhoods. The act contained three important provisions: 1) quantitative targets for purchases of loans made to low-income borrowers and in lowincome and minority neighborhoods; 2) a mandate that the GovernmentSponsored Enterprises "lead the industry in affordable lending" through financing innovative pilots; and 3) language that prohibits the GSEs from discriminating based on prohibited factors, such as a borrower's race, ethnicity, or gender, in their loan purchase activities (Temkin \& Ferguson, 2004).

As a result of these efforts, the government successfully led the market in the adoption of: more flexible standard conventional lending guidelines that allowed private lenders to serve borrowers with little equity, less than perfect credit, and relatively high levels of debt; and affordable lending programs that allowed more underwriting flexibility for eligible borrowers 
than do standard conventional loans (Temkin \& Ferguson, 2004). These efforts, however, spurred a housing bubble in 2006-2007 as the same secondary markets used to hedge risk through Mortgage-Backed Securities (MBS), created a boom in riskier and predatory mortgage products. Starting in the early 1990s, banks and other financial institutions began widely adopting a practice known as "securitization", which allowed banks to package together illiquid assets such as mortgages, and sell them as securities to investors. Pushed by regulatory pressure to extend lending to riskier clients, banks saw securitization as a way to transfer risk associated with defaulting mortgages from the banks to the investors, and thereby offer riskier clients a financially accessible interest rate (Demyanyk \& Hemert, 2008).

This created a boom in subprime loans, increasing from the historical $4.5 \%$ of new loan origination in 2000 to $20 \%$ by 2006 (Inside Mortgage Finance, 2007). With real estate values surging, increased competition between banks for subprime clients led to a deterioration of underwriting that created a surge in nontraditional mortgage loan features. Examples of these features include adjustable rate mortgages (ARM), interest-only mortgages, pay option mortgages, and mortgages with large final payments known as "balloon payments". When real estate prices began to stagnate, however, and banks raised loan interest rates to hedge against loses, many of the nontraditional mortgage features that had made mortgages accessible, quickly made the loans unsustainable. Since subprime loans with nontraditional features were mostly targeted and attractive to lower-income, poorer credit households, when rates increased sharply on new bank loans, subprime features followed suit in 2007-2008, producing a wave of defaults.

Since national and international investors in MBS shared the default risks, ballooning defaults wiped out the assets of a much wider audience than the original lending institution. Consequently, a new wave of regulatory protections came in the aftermath of the crisis, intended to maintain a safe level of mortgage lending to borrowers. Despite this renewed focus on safe mortgage lending to new homeowners, little attention has been given to existing homeowners who now have limited capacity to maintain their homes. According to David Dangler of Neighborhood Reinvestment Corporation:

Nonprofits, like Habitat for Humanity, have rushed in to provide rehab and post-purchase programs for low-income homeowners, however these programs are limited in funding, hence scale. As the number and percentage of owner-occupied households below the poverty level has 
continued to increase over the past five years the ability to afford housing maintenance becomes a greater concern (US Census Bureau, 2007-2013).

Nonetheless, private microloans for rehabilitation of aging housing stock have had success in the past. MFIs, like ShoreBank, in Chicago, have proven since 1973 the economic viability of using microloans to rehabilitate aging homes in low-income markets. With all this said, U.S. MFIs discovered that HMF in the U.S. presents a unique set of challenges beyond the existing tensions with lending to riskier clients. Some arguments are presented, as compared with microenterprise finance:

- Cost versus affordability: Interest rates for microenterprise finance are generally set much higher than prime rates for mortgage, while U.S. nonprofit lenders resist charging high interest rates in order to increase affordability (Ferguson \& Haider, 2002).

- Term mismatch and interest-rate risk: In the U.S. secondary market institutions, such as Fannie, Mae, Freddie Mac, and the Federal Home Loan Bank System, better allocate the risk of mortgage lending to investors. As a result, borrowers can reduce their payments by extending the loan term (Ferguson \& Haider, 2002). Investors are given fiscal incentives to buy secondary mortgage debt instruments (e.g. mortgage investments were tax exempt, could be used as part of the legal reserve of commercial banks, and were compulsory assets in insurance companies).

- Underwriting/credit analysis: In housing microfinance, where the house is used as collateral, the Loan-to-Value ratio is very important, as it ensures the lender can recuperate its losses, should the borrower default. While it is much easier to foreclose on property in the U.S. than in other countries, it is still expensive to do, and many nonprofit or missiondriven organizations go to great lengths to avoid doing so, undermining HMFIs' ability to effectively manage risk.

- Technical assistance: In the U.S., zoning laws limit or outright prohibit progressive building in many places, making the building process more complex and rife for housing code violations, if done incorrectly. Lending directly to homeowners or small-scale developers who are less experienced, HMF institutions in the U.S. usually require more hands on assistance and oversight, increasing their operating costs.

- Loan security and collateral: Unlike microenterprise finance, HMF does not use group lending for two reasons: 1) housing lenders work in many 
communities, thus fail to create the needed peer pressure that is created by those that focus intensively on one neighborhood or village; 2) the larger loan amounts and longer terms of housing loan impose greater risk on other members (Ferguson \& Haider, 2002).

\subsection{HMF for routine maintenance \& home improvements}

HMF for housing repair might be a more viable market for microfinance. According to a study by the National Center for Healthy Housing ( $\mathrm{NCHH}$, 2013), $40 \%$ of metropolitan homes in the U.S. contain one or more health and safety hazards, indicating a 5\% decline in housing quality since the 2009 census at the height of the foreclosure crisis.

According to research by Huh and Kolluri (2004), this problem is greater in central cities than in suburbs, due in part to older housing stock, costlier house maintenance (e.g. historic preservation), and a greater concentration of low-income households. Belsky (2004) estimates that $45 \%$ of extremely low-income homeowners have difficulty properly maintaining their homes because they spend more than half their income on other housing costs; and about $20 \%$ of low-income homeowners have a tough time accessing credit for home repairs and improvements for the same reason.

\section{METHODOLOGICAL APPROACH}

The general methodological approach will be qualitative research on how microfinance for housing repair works within the market context of Baltimore City, leveraging secondary government and private research, along with primary interviews with lenders and borrowers.

Due to the lack of research specifically on HMF in the U.S., along with a lack of MFIs that do HMF work, this paper pursued an exploratory model that used semi-structured interviews to understand nuances in the HMF lending market. This qualitative approach to inquiry allowed "the collection of data in a natural setting sensitive to the people and places under study, and a data analysis that is inductive and establishes patterns or themes" (Creswell, 2007, p. 37).

Baltimore City was selected as it has one of the highest poverty rates in its region (Sandoval, 2015) and one of the largest unbanked and underbanked populations in the country (Kast \& Harvie, 2016).

Founded in 1729, before American independence, Baltimore City has an older housing stock than the U.S. average - 44 years old versus 40 (AHS, 2013). 
Reaching its peak population of over 900,000 in the 1970s as a major manufacturing and port city, the city's population has declined by over $30 \%$ due to deindustrialization and a shift to services industry (Lazarick, 2015). Consequently, 16,000 houses have remained uninhabitable within the city limits, with an additional 46,800 homes that are vacant - approximately $10.1 \%$ of Baltimore's housing stock (McCoy, 2015). This clustering of high vacancy in the city reduces the property value of neighboring occupied homes, and increases the need for repair. Additionally, the concentration of poverty in the city, along with the poor tending to live in older housing stock, makes the ability to make these repairs less economically feasible. While a number of programs in Baltimore focus on first-time home purchase and rehabilitation, very few focus on property upkeep for those who already have homes (Huh \& Kolluri, 2004). Low-income Baltimorean homeowners are also less likely to have access to a home equity loan (AHS, 2013) with lower income, leaving them to their savings, credit cards or alternative financial services (like payday loans or check cashing stores). This creditfinancing gap may provide an opportunity for microfinance to play a role.

In total, six Baltimore homeowners and four organizations were interviewed: three non-profits and one government entity. All interviews were done by phone. This was in part because the researcher did not have resources to invest on mobility to achieve and interview people in-person, and many of the interviewees did not have computer or limited or no accessibility to Skype. During each phone interview, the researcher took notes and recorded them, when allowed by the interviewee. While the questions for both homeowners and lenders followed a basic format, they were mostly open-ended and semi-structured. The typical interview ran about 30 minutes; however interviewee engagement often dictated the length and quality of content. The flexible structure allows interviewers to "probe" interviewers, where further explanation is needed (Saunders, Lewis, \& Thornhill, 2007).

\section{ANALYSIS}

After the interviews, this paper analyzed the data using PESTEL framework. PESTEL describes the macro-environmental context in the U.S. and Baltimore.

The framework relies on a combination of primary and secondary data. The primary data for Baltimore includes phone interviews with Baltimore 
lenders and homeowners; secondary data draws heavily from U.S. Census data, and university and private sector analysis on access to credit and housing repair trends. The purpose of the frameworks is to develop a deeper understanding of the barriers to scale and fiscal sustainability for both lenders and borrowers in Baltimore and the US.

\subsection{Pestel}

PESTEL is a mnemonic for identifying the Political, Economic, Social, Technological, Environmental, and Legal factors that shape an industry. This PESTEL analysis is used to describe the Housing Microfinance (HMF) industry in the U.S. and Baltimore, and will weave together primary data from the aforementioned interviews and survey, along with U.S. Census data, and secondary data from industry reports.

\subsubsection{Political}

These factors determine the extent to which a government may influence the economy or a certain industry. The major political events that shape the HMF sector are:

1974 Community Development Block Grant: ever since President Lyndon B. Johnson's "War on Poverty" in the 1960s, a number of social programs became targeted at making housing maintenance more affordable for the poor. In 1974 President Gerald Ford signed the Housing and Community Development Act, which created the Community Development Block Grant (CDBG) program. CDBG's core program guaranteed access to funding to cities and counties based on a need-based formula, for the purpose of "providing decent housing and a suitable living environment, and by expanding economic opportunities, principally for low- and moderate-income persons" (CDBG Entitlement Program Eligibility Requirements, 2016). While each recipient has great flexibility in determining fund usage in collaboration with the target population, some cities, such as Baltimore, have used it to help low-income homeowners maintain their homes (CDBG Application and Forms, 2016). This is a major source of funding for Baltimore lenders, such as Health Neighborhoods.

1977 Community Reinvestment Act (CRA): in 1977, the Community Reinvestment Act (CRA) required federally-regulated banks to extend credit to low-income communities in which they were chartered, leading to a new funding stream for MFIs that included housing repair and renovation purposes (Williams, 2004; Meeks, 2012). 
1978 Neighborhood Reinvestment Corporation Act (NeighborWorks America): CRA was followed by the Neighborhood Reinvestment Act (renamed NeighborWorks America in 2005), which scaled up a model of urban redevelopment that trained local stakeholders (public and private) to pool resources to address the housing needs of low-income communities (FDIC Law, Regulations, Related Acts, 2016). These branches span all 50 states, and typically support non-profit chapters that also offer products and programs to help homeowners with repairs and renovations.

\subsubsection{Economic}

These are factors in the economy that directly impact a HMFIs performance and business model.

National: the American economy has largely recovered to pre-Great Recession economic indicators, but with a much tighter credit market, especially for mortgages. Home equity has also been wiped out for many households as a mechanism to finance repairs and renovations, and while foreclosure rates have come down, they still remain above pre-recession levels (Joint Center for Housing Studies, 2016). Spending on home improvement has returned to pre-recession levels, despite high foreclosure rates, and interest rates set by the Federal Reserve remain at historic lows to spur economic growth. Since the recovery began in 2009, interest rates have slowly increased over the past two years and inflation has remained low (Improving America's housing stock, one loan at a time, 2016), and policymakers have been especially leery of increasing tax burdens (Improving America's housing stock, one loan at a time, 2016; Kiersz, 2015). In this environment MFIs have seen an increased demand for their services, but an overall reduction in their own access to credit (IFC, 6).

The HMF industry also still faces long-term structural barriers. While credit has become more difficult to obtain, credit cards still provide an easier option for Americans to finance small repairs than working with an MFI (Improving America's housing stock, one loan at a time, 2016).

Wage employment is the standard in the U.S., unlike in developing countries where residents may have a larger self-employment and informal sector with irregular cash flow (Fields, 2014). As such, the market is accustomed to a monthly billing structure that fits the cash flow of the average consumer. Loan products that do not conform to this structure may experience higher rates of default as a result.

Baltimore: while the city has experienced economic recovery with the rest of the country, it has been slow to regain its labor participation rates 
relative to others, and continues to combat a very stubborn poverty rate that is concentrated in the region. The poverty rate is at $23 \%$ compared to $9.7 \%$ in the State of Maryland, and 13.5\% nationally (U.S. Census, 2015). Generally, lower-income homeowners live in older housing, in part because it is cheaper, but also because older households tend to live on fixed income. Either way, older homes often require more maintenance and renovation than newer homes. Combined with higher likelihood of subprime credit scores, low-income Baltimore homeowners may experience reduced access to credit to finance these home improvements, which HMFIs could provide.

\subsubsection{Social}

These factors analyze the social environment of the market, and evaluate components like cultural trends, demographics, population analytics, etc.

National: demographic shifts now indicate that Millennials (born between 1980-1999) are now the largest living group, and place the highest value on social responsible investing (Spectrem Group, 2015; U.S. Chamber of Commerce Foundation, 2012) While Millennial distrust of corporations and banks is high, organizations with a social mission, such as impact investing, earn support (Deloitte, 4). Despite this trend, the group spending the most on home improvements is still the elderly. Older homeowners account for a large share of home improvement, spending nearly $\$ 90$ billion in 2013, and the increasing number of households aging in place will drive up home improvement volume in the foreseeable future (Improving America's housing stock, one loan at a time, 2016).

Baltimore: prospects for scale might be relatively better in the Baltimore City, which has one of the lowest median household incomes in the region ( $\$ 41,819$ in 2014) and also an older housing stock (McDonald, 2014). While Baltimore has seen the most population growth among Millennials, elderly homeowners remain the biggest spenders for home improvements in Baltimore, as they make up a higher percentage of homeowners and tend to live in older housing stock (AHS, 2013). From homeowner interviews, there is a general cultural preference against bank loans altogether. When asked about taking out private bank loans, one homeowner confessed:

In my experience, if you can avoid it, avoid it. I still think there are areas...where there is redlining... they're not going to give you the loan, or the interest rates are going to be so high, based on either your credit score or the area that you live in. And I found that for me to be... a reality. And then the programs that I worked with were just for 
people in need, and worked out to our advantage. Without these programs, I would be in an entirely different financial situation (Middleton, Homeowner Interviewee 5).

Middleton went on to explain that having programs designed for people in his situation, who were willing to work with him as far as flexible underwriting and loan terms, was critical. Johnson also confirmed that his initial home loan through a Catholic nonprofit called St. Ambrose was fundamental in his ability to secure housing and maintain it (Johnson, Homeowner Interviewee 2).

This general aversion to taking on debt was echoed through the interviews and heard most loudly by those using their homes as collateral. Jim Hix from Baltimore Housing noted that even more than denying people for low LTV, the top reason for denial is that the applicant - usually elderly simply did not want to put a lien on their property because "I don't want the City to come take my house!" (Hix, Lender Interview 3). One resident mentioned that she didn't want to pass down debt to her children by having a lien on her home (Blanding, Homeowner Interviewee 7), and yet another resident mentioned that having his home "free and clear" (Johnson, Homeowner Interviewee 1) gave him a sense of "freedom" that he and his wife would always have a home.

\subsubsection{Technological}

These factors related to innovations in technology that may affect the operations of the industry and the market favorably or unfavorably.

As mentioned in Social, millennials are the largest demographic group in the US. Combined with their heightened social consciousness, they are also the most technologically connected and savvy. This has led to the proliferation of crowdfunding platforms for social good such as Kiva.org and StartSomeGood.com, and the organizing of the industry into the Global Impact Investing Network in 2009. These trends related to millennial preferences make HMF institutions a natural fit for investment and growth, especially if they do a good job making the experience technologically efficient (i.e. an online platform), and personally gratifying (i.e. making the investor feel personally connected to the person or project) (Keng, 2009)

This likely means MFIs will need to budget and invest more in technology for the investor, while still providing an accessible community presence for clients; both types of investments can be expensive. Physical presence is essential for the MFI to truly understand the client and offer the right 
financial products and terms, which are crucial to expanding access to finance to riskier populations. Flexible underwriting, shorter loan terms, lower loan amounts, and frequent payments are microfinance innovations that all require more intense client-lender interaction (Christen, 2004). Furthermore, with increased lending regulation forcing lending institutions to require greater certainty of borrower "ability to repay," more documentation will be needed. Streamlining these processes to reduce the burden on the borrower will be crucial in maintaining competiveness with credit cards.

\subsubsection{Environmental}

These factors include all those that influence or are determined by the surrounding built environment.

Since Baltimore's housing stock is older than those in other areas of the state, several government programs exist to help low and middle-income homeowners upgrade the energy efficiency of their homes, as well as upgrade core systems such as HVAC and plumbing (Baltimore Housing, 2016). These programs might compete with microloan products for these needs. The city also has a very high vacant housing stock that creates additional structural burdens to neighbors attached to one. One resident, living between two vacant properties, said:

The house 1917 [next door] porch roof collapse, and it collapsed right onto my porch, and the house at 1913 [rowhouse on other side of resident]... [the City] had to contain the leak that was coming through to my side of the building...the mere fact that the house was vacant causes distress...they [insurance companies] make it impossible for people to get homeowners insurance when they have vacancies right next door (Robinson, Homeowner Interviewee 2).

Concentration of vacant and abandoned houses also lowers the value of surrounding homes, impairing the use of homeowner equity for loans. Multiple lenders cited this as an issue in being able to approve loans. This further exacerbates the gap between the need for repairs and access to credit that a HMFI could provide.

\subsubsection{Legal}

This section focuses on the legal framework that impacts the business environment within the U.S. and Baltimore, in efforts to highlight areas that MFIs will need to address for successful market entry. 
CDFI Certification \& Funding: in 1994, the Riegle Community Development and Regulatory Improvement Act created a government agency that provides funding to CDFIs and acts as a gatekeeper by providing CDFI certification, required to receive money from the CDFI Fund. Most MFIs are CDFIs, especially since CRA was updated in 1995 to allow loans and investments in CDFIs to qualify as a CRA activity. Many traditional banks look for CDFI certification to ensure that their donations count towards their CRA requirements. For the MFI this means that in order to remain competitive for private and government funding, it will need CDFI certification. This increases the barrier to market entry and sustainability.

Consumer Protection Laws: at the Federal level, no interest cap exists on loans, however, all lenders must disclosure interest rates and final costs in a transparent manner. This is governed by the Federal Trade Commission through the Truth in Lending Act of 1968. Since the Great Recession, Congress has created the Consumer Financial Protection Bureau in 2011, which has increased regulation ensuring borrowers have the "ability to repay" mortgage loans, and are generally better informed. While these new regulations are meant to protect the consumer, they may also have a chilling effect even beyond mortgage lending. Omar Marshall, of Neighborhood Housing Services mentioned that:

We have lower interest rates and have a community mission... but we still have to operate as a lender...if LTV, DTI Debt-to-Income] aren't there... and with the new TRID [TILA-RESPA Integrated Disclosure] laws we have to be very careful about creating a loan for someone that isn't ready for it...the goal isn't to get them into further debt...[but] to repair their home (Lender Interviewee 3).

At the State-level, however, interest rate caps abound and differ by state. Baltimore City, for example, is governed by interest rates set by the State of Maryland through the Commissioner of Financial Regulation. Most lenders are required to be licensed by the Commissioner of Financial Regulation. Annual interest rate caps currently range from $24-33 \%$ depending on loan size (Department of Labor, License and Regulation, 2016). Consumer protection has its place, but because the supply of microfinance to the poor costs more than supply of traditional finance to the non-poor, the poor will likely have to pay more, if they are to have sustainable, ongoing access to finance (Schreiner \& Morduch, 2002). U.S. MFIs typically charge interest rates that are slightly above prime (e.g. in Los Angeles, Accion East and Online Women's Program interest rates range from 8 to 15\%) and use a mix 
of government, foundation, and private donations to cover operating costs (Microlending in the United States, 2016). HMFIs, however, tend to charge below prime interest rates to ensure "affordability."

Zoning Laws: microfinance for housing is less common in the U.S., because state and local laws impede progressive home improvements to low-cost - starter homes. Few poor people build their own homes, and small repairs and improvements may be financed by credit cards or home-equity loans. These options exist due to a stable macroeconomy (that assures low, stable inflation over long periods of time), extensive credit bureaus and credit-scoring systems, abundant wage jobs (used as proof of ability to pay), and a legal system that facilitates relatively inexpensive foreclosure. For legal reasons, larger home improvements are often left to professionals; for safety and to protect the value of neighboring houses local governments make and enforce building codes and zoning laws. While these laws serve valid purposes, they also constrain access to small, low-cost houses because they increase minimum cost of a house and limit progressive improvements once the home is built (Schreiner \& Morduch, 2002). Due to this complexity, MFIs entering the market will need to budget for training costs to help borrowers choose qualified contractors to do work up to housing code.

\subsection{Pestel summary}

The market for HMF loan products in Baltimore closely matches the academic literature regarding microfinance in the U.S. generally. The same structural costs exist as it pertains to high government regulation costs in labor, zoning and consumer protection laws. Baltimore lenders also share in the trend toward high training and personalization costs. At the same time, similar market demands exist as they relate to an increasingly aging housing stock, and population. Baltimore's housing stock tends to be older, and has a greater concentration of poverty, both factors making the demand for HMF products potentially higher than other areas of the country. Lender supply of financing also seems "healthy," but it is mostly from philanthropic or government sources, not from loan interest, which forces lenders to abide by certain rules that favor "affordability" over financial sustainability.

\section{CONCLUSIONS}

How can microfinance be applied to housing repair in Baltimore?

The main assumption this paper makes is that microfinance for housing repair in the U.S. would be more financially self-sufficient due to its 
recurring, cyclical need that is unlike microloans to businesses. While there are populations excluded from the home maintenance and improvement markets, and a stable supply of financing for home repair loans, the macroeconomic and industry analyses (PESTEL) demonstrate that there is no financially sustainable model in the current HMF sector in Baltimore.

The qualitative research from Baltimore is consistent with previous academic research about microfinance in the U.S. in that it is not being applied in the classical model, established by Muhammad Yunus. The Baltimore analysis confirms the need for partnership with private and public entities for ongoing capital and operating support, and the greater availability of credit in the U.S. through credit cards that reduces the market size for small-dollar HMF products. What Baltimore demonstrates is that HMF, unlike microloans for businesses, is especially impacted by heavily subsidized interest rates due to government and philanthropic priorities in housing that does not value financial sustainability. Baltimore also demonstrates the strong impact of high vacancy rates that limits the home equity line-ofcredit available for homeowners.

If HMFIs want to enter into this market, they will need to shift their financial model from the classical self-sustaining microfinance model, to one that permanently depends on banking support for loan capital, and philanthropic support for operations. Because HMFIs cannot afford to compete on already low interest rates, a successful new entrant will have to pursue a differentiation strategy, i.e. create a unique HMF product or experience that sets it apart from other providers. Due to the limitations of data collection, and the uniqueness of the Baltimore market, these conclusions cannot necessarily be generalized to other U.S. cities that are structurally different, e.g. have newer housing stock, greater number of financial institutions, or lower rate of vacant/abandoned housing. Nonetheless, some of the structural challenges in the overall U.S. market for microlending for housing, such as the ease of credit cards and other financing alternatives, the government and philanthropic subsidizing of interest rates, and the intensive training requirements for microlending, all make reaching financial sustainability more difficult for HMFIs than for traditional MFIs.

\section{$\int$ REFERENCES}

Armendáriz, B., \& Morduch, J. (2005). The Economics of Microfinance. Cambridge: The MIT Press. 
Baltimore Housing. (2016). Rehabilitation Services. Retrieved from http:// www.baltimorehousing.org/rehabilitation

Bates, T., \& Servon, L. J. (2002) Microenterprise as an exit route from poverty: Recommendations for programs and policy makers. In J. Carr \& Z. Tong, Replicating Microfinance in the United States (p. 21). Washington, D.C.: Fannie Mae Foundation.

Belsky, E. S. (2004). Rehabilitation matters: Improving neighborhoods one home at a time. In F. Daphnis \& B. Ferguson, Housing microfinance: A guide to practice (p. 186). Boulder: Kumarian Press.

Bhatt, N. (2002). Alleviating poverty in the global metropolis: The social enterprise promise. In J. Carr \& Z. Tong, Replicating Microfinance in the United States (p. 21). Washington, DC: Fannie Mae Found.

Carr, J., \& Tong, Z. (2002). Introduction: Replicating microfinance in the United States: An overview. In J. Carr \& Z. Tong. Replicating microfinance in the United States (pp. 1-15). Washington, DC: Fannie Mae Foundation.

Christen, R. (2004). Foreword. In F. Daphnis \& B. Ferguson. Housing microfinance: A guide to practice (pp. 9-18). Boulder, Colorado: Kumarian Press.

Creswell, J. W. (2007). Qualitative inquiry and research design: Choosing among five approaches (2nd ed.). Thousand Oaks, CA: Sage.

Daphnis, F. (2004). Elements of product design for housing microfinance. In F. Daphnis \& B. Ferguson, Housing microfinance: A guide to practice (p. 33). Boulder: Kumarian Press.

Demyanyk, Y. S., \& Hemert, O. van. (2008). Understanding the Subprime Mortgage Crisis. SSRN Library. doi 0.2139/ssrn.1020396

Department of Labor, License and Regulation. (2016). Payday Day Loans: Financial regulation. Retrieved from http://www.dllr.state.md.us/finance/ consumers/paydayloans.shtml

Ferguson, B., \& Haider, E. (2002). Microfinance of progressive housing. In J. Carr \& Z. Tong, Replicating microfinance in the United States (pp. 299-328). Washington, DC: Fannie Mae Foundation.

FIELD. (2015). U.S. microenterprise census highlights, FY 2013. Retrieved from The Aspen Institute website https://www.aspeninstitute.org/publications/ u-s-microenterprise-census-highlights-fy-2013/

Fields, G. S. (2014). Self-employment and poverty in developing countries. IZA World of Labor, 60, pp. 1-10. Retrieved from https://wol.iza.org/ articles/self-employment-and-poverty-in-developing-countries/long 
Girardo, W., \& Edgcomb, E. L. (2011). Key data on the scale of microlending in the U.S. Retrieved from FIELD, The Aspen Institute website: http://fieldus. org/Publications/Microfinancing.pdf.

Hahn, R. (2008). Microfinance is the new subprime. The World Bank. Retrieved from < http://blogs.worldbank.org/psd/microfinance-is-the-new-subprime Housing Microfinance Initiatives (2000). Retrieved from United States Agency for International Development website: http://pdf.usaid.gov/pdf docs/Pnadb892.pdf

Huh, K., \& Kolluri, L. P. (2004). The market for housing microfinance in the United States. In F. Daphnis \& B. Ferguson, Housing microfinance: A guide to practice (pp. 175-199). Boulder: Kumarian Press.

Improving America's housing stock, one loan at a time. (2015, March 31). Freddie Mac. Retrieved from http://www.freddiemac.com/research/ insight/20160331_insight_improving_americas_housing_stock.html

Inside Mortgage Finance. (2007). Mortgage market statistical annual 2007. Bethesda: Inside Mortgage Finance Publications. Retrieved from https:// www.insidemortgagefinance.com/catalog/newsletters/-1000007533-1. html

Joint Center for Housing Studies. (2016). Homeownership. Cambridge: Harvard University, 2016. Retrieved from http://www.jchs.harvard.edu/ sites/jchs.harvard.edu /files/son_2016_200dpi_ch4.pdf

Kast, S., \& Harvie, M. (2016, February 10). Unbanked in Baltimore. WYPR. Retrieved from http://wypr.org/post/unbanked-baltimore

Keng, M. (2009). The impact of the economic recession on microfinance institutions in the United States (PhD thesis). Retrieved from http://cdmbuntu.lib.utah. edu/utils/getfile/collection/etd2/id/1387/filename/2079.pdf

Kiersz, A. (2015). 28 charts that show how America changed since the Fed gave us 0\% rates. Business Insider. Retrieved from http://www.businessinsider. com/economic-indicators-since-great-recession-zero-interest-rate-policy2015-9/

Lazarick, L. (2015, October 6). What to do about Baltimore's high taxes? Maryland Reporter. Retrieved from http://marylandreporter.com/2015/ 10/06/what-to-do-about-baltimores-high-taxes/

Listokin, D., \& Crossney, K. (2006). Best practices for effecting the rehabilitation of affordable housing (Vol. 1). Retrieved from U.S. Department of Housing and Urban Development, Policy Development and Research website: https://www.huduser.gov/portal/publications/pdf/BarriersVol1_part1.pdf 
Louie, J., Belsky, E. S., \& McArdle, N. (2004). The housing needs of lowerincome homeowners. In F. Daphnis \& B. Ferguson, Housing microfinance: A guide to practice (p. 188). Boulder, CO: Kumarian Press.

McCoy, T. (2015, May 12). Baltimore has more than 16,000 vacant houses. Why can't the homeless move in? The Washington Post, 2015. Retrieved from https://www.washingtonpost.com/local/baltimore-has-more-than16000-vacant-houses-why-cant-the-homeless-move-in/2015/05/12/ 3fd6b068-f7ed-11e4-9030-b4732caefe81_story.html

McDonald, R. (2014, August 14). Nearly a quarter of Baltimore's housing stock was built before 1950. Baltimore Business Journal. Retrieved from http://www.bizjournals.com/baltimore/blog/real-estate/2014/08/nearlya-quarter-of-baltimores-housing-stock-was.html

Meeks, J. (2012). An Introduction to the Community Reinvestment Act. Retrieved from $<$ https://www.richmondfed.org/ /media/richmondfedorg/conferences_ and_events/community $>$

Brazil market overview. (2017). Retrieved from Microfinance Information Exchange website: https://www.themix.org/mixmarket/countriesregions/ brazil?order $=$ gross_loan_portfolio\&sort $=$ desc

National Small Business Association. (2012). NSBA survey: Small business outlook significantly improved. Retrieved from http://www.nsba.biz/?p=12115

National Center for Healthy Housing. (2013) NCHH Unveils Latest State of Healthy Housing. Retrieved from http://www.nchh.org/tabid/139/default. aspx?ContentID $=176$

Saunders, M., Lewis, P., \& Thornhill, A. (2007). Research methods for business students. Harlow: Financial Times/Prentice Hall.

Sandoval, T. (2015, December 14). This map shows you where most poverty is concentrated in Maryland. Baltimore Business Journal. Retrieved from https://www.bizjournals.com/baltimore/news/2015/12/14/this-mapshows-you-where-most-poverty-is.html

Schreiner, M., \& Morduch, J. (2002). Opportunities and challenges for microfinance in the United States. In J. Carr \& Z. Tong (Eds.). Replicating microfinance in the United States (pp. 19-61). Washington, DC: Fannie Mae Foundation.

Spectrem Group. (2015). Millennial investors more socially responsible with investment choices. Retrieved from http://spectrem.com/Content/MillennialInvestors-Have-Greater-Concern-Over-Social-Responsibility.aspx.

Swibel, M. (2007, December 20). The 50 top microfinance institutions. Forbes. Retrieved from http://www.forbes.com/2007/12/20/microfinancephilanthropy-credit-biz-cz_ms_1220microfinance_table.html. 
Taub, R. P. (2002). Making the adaptation across cultures and societies: A report on an attempt to clone the Grameen Bank in Southern Arkansas. In J. Carr \& Z. Tong, Replicating Microfinance in the United States (p. 21). Washington, DC: Fannie Mae Foundation.

Temkin, K., \& Ferguson, B. (2004). The context for housing microfinance in the United States. In F. Daphnis \& B. Ferguson, Housing microfinance: A guide to practice (pp. 151-173). Boulder, CO: Kumarian Press.

U.S. Department of Housing and Urban Development. (2016). FY 2016 HUD Income Limits Briefing Material. Retrieved from U.S. Department of Housing and Urban Development website: https://www.huduser.gov/portal/ datasets/il/il16/IncomeLimitsBriefingMaterial-FY16.pdf

Williams, R. (2004). The effects of GSEs, CRA, and institutional characteristics on home mortgage lending to underserved markets. In $\mathrm{F}$. Daphnis \& B. Ferguson, Housing microfinance: A guide to practice (p. 154). Boulder, CO: Kumarian Press.

\title{
ABOUT THE AUTHORS
}

\author{
ANTHONY SCOTT \\ $\mathrm{PhD}$ in Public Administration, \\ Columbia University. \\ Special Assistant to the Chief of Strategic Alliances, \\ City of Baltimore, Mayor's Office. \\ 100 North Holliday Street, Baltimore - Maryland - USA - 21202. \\ E-mail: anthony.scott@baltimorecity.gov \\ ORCID: 0000-0002-0487-7390

\section{LAURO GONZALEZ} \\ $\mathrm{PhD}$ in Business Administration, \\ Escola de Administração de Empresas de São Paulo. \\ Professor at the Department of Finance, \\ Escola de Administração de Empresas de São Paulo. \\ Rua Itapeva, 474, Bela Vista - São Paulo - SP - Brazil - CEP 01332-010 \\ E-mail: lauro.gonzalez@fgv.br \\ ORCID: 0000-0001-9316-6525

\section{TANIA PEREIRA CHRISTOPOULOS} \\ $\mathrm{PhD}$ in Public Administration, \\ Escola de Administração de Empresas de São Paulo. \\ Assistant Professor at the Department of Marketing/Sustainability, \\ Universidade de São Paulo. \\ Rua Arlindo Bétio, 1000, Ermelino Matarazzo - São Paulo - SP - Brazil - CEP 03828-000 \\ E-mail: tchristo@usp.br \\ ORCID: 0000-0001-6310-3216
}


Anthony Scott, Lauro Gonzalez e Tania Pereira Christopoulos

\section{EDITORIAL BOARD}

Editor-in-chief

Silvio Popadiuk

Associated Editor

Dimária Silva e Meirelles

Technical Support

Patricia Betencourt

Vitória Batista Santos Silva

\section{EDITORIAL PRODUCTION}

Publishing Coordination

Irina Migliari

Language Editor

Caio Rubens Salles

Editorial Trainee

Maria Luiza Vanz

Layout Designer

Emap

Copyeditor

Irina Migliari

Graphic Designer

Libro 